Article

\title{
Electrochemical Biosensor for the Determination of Amlodipine Besylate Based on Gelatin-Polyaniline Iron Oxide Biocomposite Film
}

\author{
Elbahi Djaalab *, Mohamed El Hadi Samar, Saida Zougar and Rochdi Kherrat \\ Laboratory of Environmental Engineering, Department of Process Engineering, Faculty of Engineering Sciences, \\ Badji Mokhtar University-Annaba, P.O. Box 12, 23000 Annaba, Algeria; samarmeh@yahoo.fr (M.E.H.S.); \\ saida.zougar@univ-annaba.dz (S.Z.); rkherrat@yahoo.fr (R.K.) \\ * Correspondence: djaalabahi@gmail.com
}

Received: 19 April 2018; Accepted: 18 May 2018; Published: 4 June 2018

\begin{abstract}
In the present study, a new biosensor based on lipase from Candida rugosa (CRL) was developed for amlodipine besylate drug (AMD) with biodegradable material using a mixture of polyaniline iron oxide and gelatin. Polyaniline $/ \mathrm{Fe}_{2} \mathrm{O}_{3}\left(\mathrm{PANI} @ \mathrm{Fe}_{2} \mathrm{O}_{3}\right)$ was prepared by a chemical polymerization method in a medium of ammonium persulfate as an oxidant and characterized by employing Scanning Electron Microscopy (SEM), Fourier Transform Infrared (FTIR), and Ultra-violet (UV) spectroscopy. The purified enzyme was entrapped in the biocomposite matrix film with the aid of a glutaraldehyde cross-linking reagent to establish the immobilization of the lipase. The principle of the biosensor is based on the electrochemical properties of amlodipine besylate (AMD), which were studied for the first time using the cyclic voltammetric method. The cathodic behavior of AMD was measured on the irreversible reduction signal at $-0.185 \mathrm{~V}$ versus $\mathrm{Ag} / \mathrm{AgCl}$ at $\mathrm{pH} 7.4$ and $30^{\circ} \mathrm{C}$ in a phosphate alkaline buffer.
\end{abstract}

Keywords: biosensors; lipase; amlodipine; polyaniline; cyclic voltammetry

\section{Introduction}

Over the past few decades, biosensors have emerged from the laboratories into the everyday life of millions of people around the world. Like some other sensors, they were first developed for the detection of particular low-molecular species, e.g., metabolites or disease biomarkers, of importance for clinical diagnostics, pharmaceutics, and the healthcare industry [1]. Biosensors have been developed and used in a wide variety of analytical fields, including environmental monitoring, chemical, physics, and biotechnology research, etc.

Conducting polymers have attracted much attention in the development of efficient biosensors. Their unique electroactive properties allow them to act as excellent substrates for the immobilization of biomolecules and rapid transfer of electrons [2-6]. Amongst the various conducting polymers, polyaniline (PANI) has been extensively studied as an important conducting material that possesses interesting electrical, electrochemical, and optical properties. The potential applications of PANI include corrosion, secondary batteries, electrochromic devices, and biosensors. In recent years, the preparation of hybrid nanocomposites with both magnetic and electrical properties has received great attention in the industrial and academic fields. Magnetic nanoparticles have been considered interesting materials for the immobilization of desired biomolecules because of their biocompatibility, strong superparamagnetic property, low toxicity, etc. [7,8]. For instance, nanocomposites based on conducting polymers and magnetic nanoparticles are some of the most widely studied materials.

Enzymatic biosensors based on polymerized films constitute an important field of pharmaceutical research $[9,10]$. Enzymes interact specifically with some substrates, and can thus be used for the 
detection of these substrates. The lipase produced by Candida rugosa is one of the most commonly used enzymes in organic solvents owing to its high activity in hydrolysis, esterification, transesterification, aminolysis, and biosensing [11-13].

Cardiovascular drugs are among the most prescribed medications nowadays since various cardiovascular diseases are predominant in developed countries worldwide. In this group, the most important drugs are antihypertensives, cardiotonics, antiarrhythmics, anticoagulants, coronary vasodilators, and hypolipemics. Since nifedipine was introduced in Germany in 1975 by Bayer AG [14], many other products such as nicardipine, nilvadipine, nitrendipine, foridone, nimodipine, benidipine, manidipine, amlodipine, felodipine, and lercanidipine have appeared on the market [15].

Amlodipine, chemically, 2-[(2-aminoethoxy)methyl]-4-(2-chlorophenyl)-1,4-dihydro-6-methyl-3,5pyridinedicarboxylic acid, 3-ethyl,5-methylester, besylate (Figure 1) [15], is a dihydropyridine calcium channel blocker, which acts only on the L-type channel to produce its pharmacological effect [16]. Like most dihydropyridine derivatives, it has greater selectivity for vascular smooth muscle than for myocardial tissue, and therefore its main effect is vasodilatation. Amlodipine is used alone or in combination with other medicines for the treatment of chronic stable angina and certain types of vasospastic angina, and in the management of mild to moderate essential hypertension.

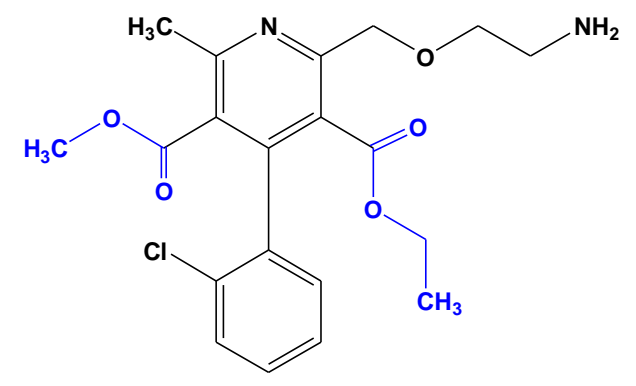

Figure 1. Chemical structures of amlodipine.

Several methods, based on various analytical techniques, have been described in the literature for the determination of amlodipine besylate in pure form as well as in chemistry laboratory formulations, pharmaceutical formulations, and biological fluids. They include spectrophotometric methods [17,18], spectrofluorometric methods [19], high-performance thin-layer chromatography [20], high-performance liquid chromatography (HPLC) [21,22], liquid chromatography (LC) [23], gas chromatography (GC) [24], capillary electrophoresis [25], flow injection analysis [26], and enzyme-linked immunosorbent assay [27].

Although these methods have high sensitivity, they are unfortunately multistep, time-consuming processes, requiring extensive pretreatment of the sample and qualification for rapid detection. In recent years, there has been increased attention focused on developing electroanalytical methods for amlodipine (AMD) analysis using gold electrodes [28], pyrolytic graphite (PG) [29], glassy carbon (GC), or carbon paste [30,31]. Considerable attention has been focused on the chemical modification of microelectrodes in order to enhance electroanalytical performance. Graphene-chitosan (GC) nanocomposite [32] and a multi-walled carbon nanotube-modified carbon paste [33] have been developed recently. In addition, boron-doped diamond (BDD) electrodes have been fabricated [34,35].

In the present work, we described the synthesis of polyaniline with iron oxide composites for fabrication in the presence of a gelatin substrate for the immobilization of Candida rugosa lipase (CRL), and then used this modified platinum electrode in amlodipine biosensor detection. The polyaniline was characterized with SEM micrography, FTIR and UV-vis spectroscopy. To the best of our knowledge, this is the first fabrication of polyaniline and gelatin for an amlodipine biosensor based on Candida rugosa lipase. In addition, the experimental conditions for fabrication and analytical performance of the biosensor were optimized with electrochemical methods. Finally, we investigated the performance of the amlodipine biosensor, based on $\mathrm{pH}$ and the temperature of the buffer solution. 


\section{Results and Discussion}

\subsection{Polyaniline Iron Oxide Characterization}

\subsubsection{Polyaniline Iron Oxide Scanning with SEM Micrography}

Figure 2a,b show the SEM micrographs displaying the surface morphology of conducting PANI@ $\mathrm{Fe}_{2} \mathrm{O}_{3}$ composites synthesized by the chemical oxidative method, in which a uniform in the surface of polyaniline was observed. The uniform distribution of $\mathrm{Fe}_{2} \mathrm{O}_{3}$ contained uniform particles that indicated the good dispersion of iron oxide on the rice straw surface.

In addition, the presence of iron oxide nanoparticles with good dispersion of $\mathrm{Fe}_{2} \mathrm{O}_{3}$ on the surface of polyaniline has a strong influence on various electrical parameters of these nanocomposites.

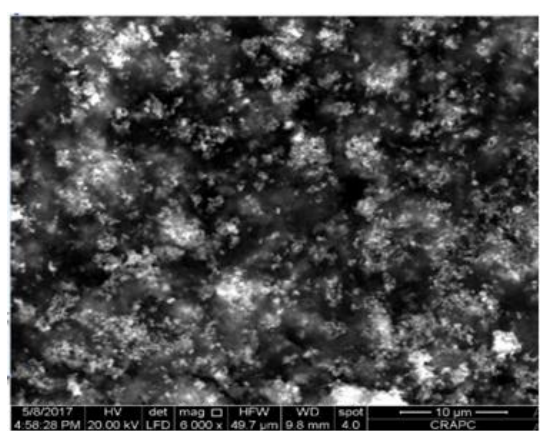

(a)

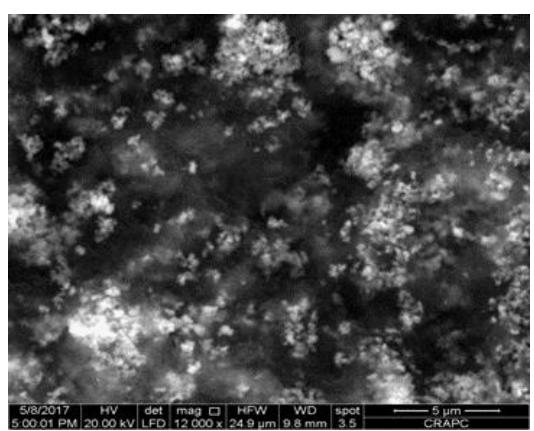

(b)

Figure 2. SEM micrographs, (a) $10 \mu \mathrm{m}$ and (b) $5 \mu \mathrm{m}$, of the surface of conducting PANI@ $\mathrm{Fe}_{2} \mathrm{O}_{3}$ composites.

\subsubsection{FTIR Spectral Characterization}

Infrared transmission spectroscopy (FTIR) has been widely used to examine conducting polymers. Figure 3a shows the FTIR spectra of PANI@Fe $\mathrm{O}_{3}$. The bands at 1599 and $1498 \mathrm{~cm}^{-1}$ of PANI (curve a) correspond to the stretching mode of $\mathrm{C}-\mathrm{N}$ and $\mathrm{C}-\mathrm{C}$ of quinoid and benzenoid rings. The bands at 1298 and $1242 \mathrm{~cm}^{-1}$ are attributed to the $\mathrm{C}-\mathrm{N}$ stretching mode of the benzenoid ring, and the signal at $1168 \mathrm{~cm}^{-1}$ is assigned to the protonated PANI $(\mathrm{N}-\mathrm{H})$. The presence of a sharp and strong band at $592-588 \mathrm{~cm}^{-1}$ indicates the presence of $\mathrm{Fe}-\mathrm{O}$ stretching vibrations. This indicates the formation of polymer composites [36]. The FTIR spectrum of $\mathrm{Fe}_{2} \mathrm{O}_{3}$ is shown in Figure 3b, with characteristic peaks originating from the Fe-O vibration in the range of $400-600 \mathrm{~cm}^{-1}$. The FTIR spectra of the PANI@ $\mathrm{Fe}_{2} \mathrm{O}_{3}$ composites showed bands at 831 and $881 \mathrm{~cm}^{-1}$, which are characteristic peaks of PANI. The peak at $684 \mathrm{~cm}^{-1}$ is usually assigned to the $\mathrm{C}-\mathrm{H}$ out of plane bending in PANI.

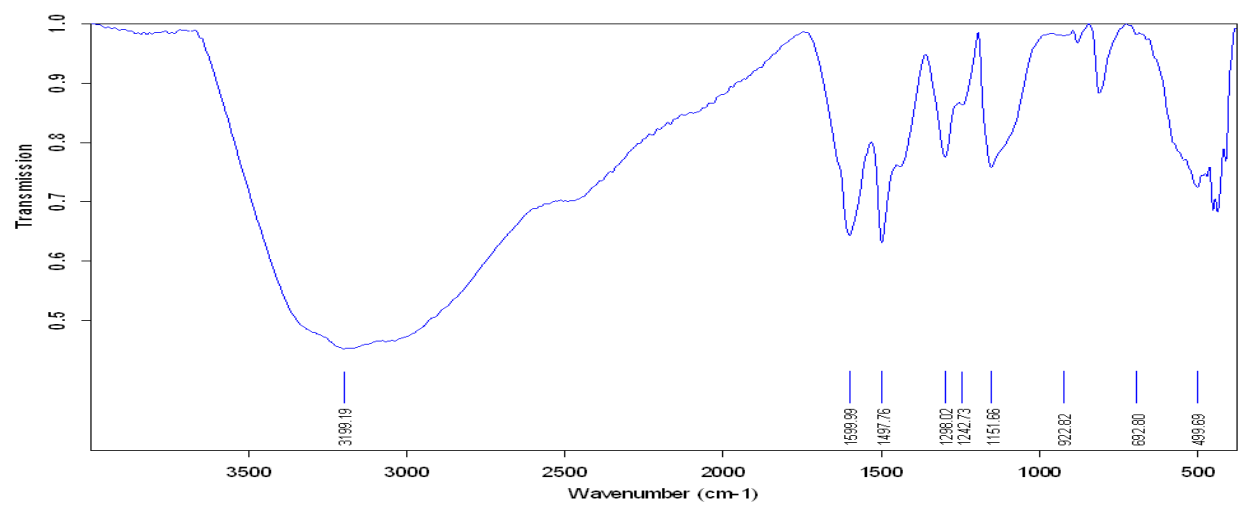

(a)

Figure 3. Cont. 


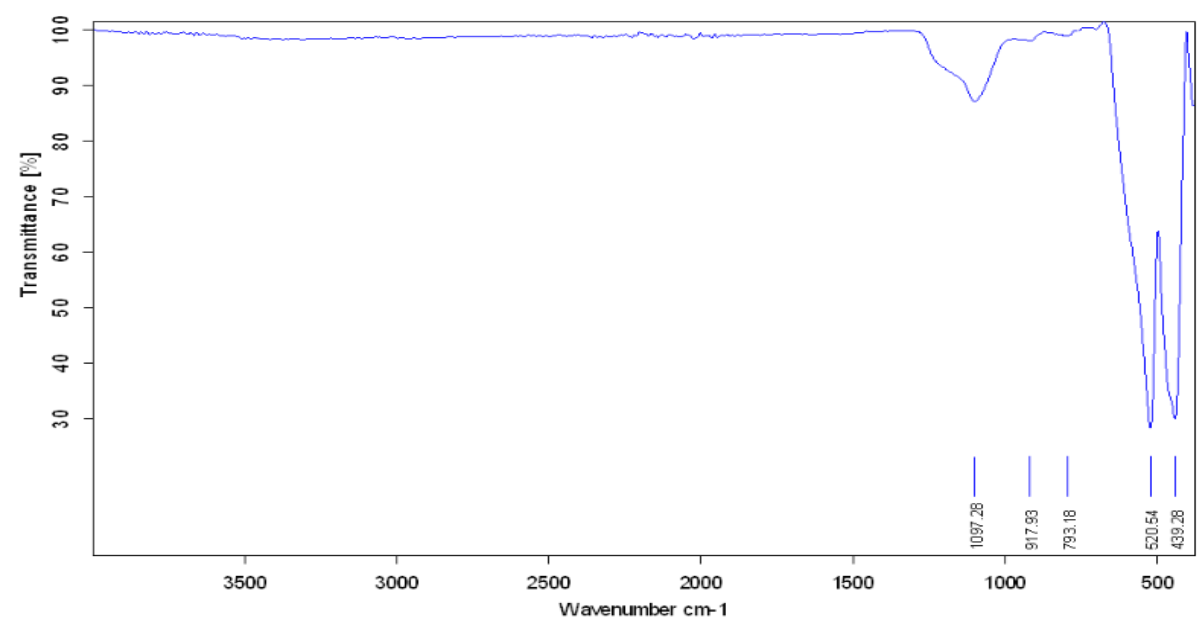

(b)

Figure 3. FT-IR spectra of (a) PANI/ $\mathrm{Fe}_{2} \mathrm{O}_{3}$ composites (b) pure $\mathrm{Fe}_{2} \mathrm{O}_{3}$.

\subsubsection{UV Spectroscopy}

The UV-vis absorption spectra of PANI/ $\mathrm{Fe}_{2} \mathrm{O}_{3}$ composite dispersions are shown in Figure 4. The typical absorption spectrum of PANI dispersions has two distinct absorption peaks at 342 and $683 \mathrm{~nm}$ after fitting (Figure 4). The peak at $343 \mathrm{~nm}$ arises from $\pi-\pi^{*}$ electron transition within benzenoid segments, and the wide peak at $683 \mathrm{~nm}$ is related to the doping level of polyaniline with iron oxide.

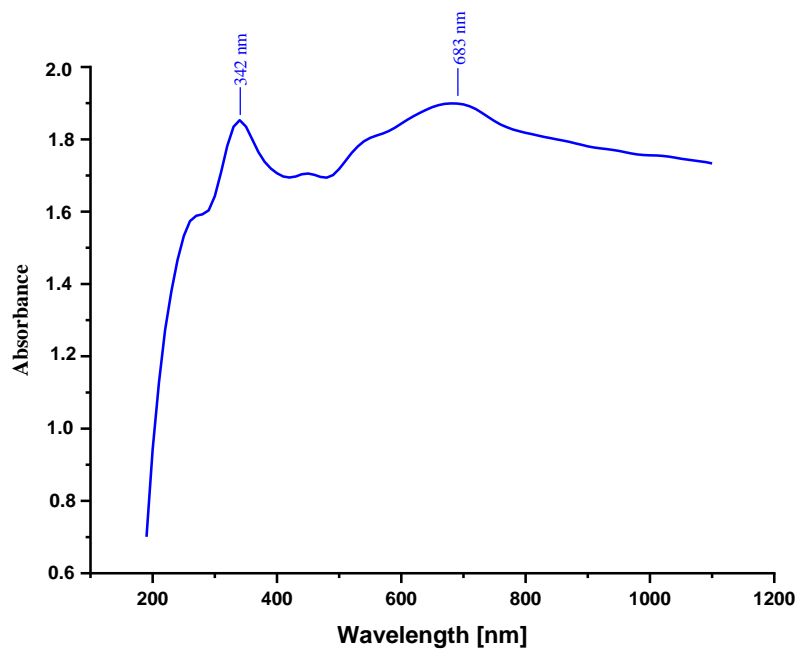

Figure 4. UV-vis spectra of PANI@ $\mathrm{Fe}_{2} \mathrm{O}_{3}$ composites.

\subsection{Electrochemical Characteristics of the Electrode Surface}

The cyclic voltammograms of soluble electro active species provide a convenient tool to monitor the various stages of the biosensor buildup on the Pt electrode.

Figure $5 \mathrm{~A}$ shows the cyclic voltammograms of the $5 \mathrm{mM}\left[\mathrm{Fe}(\mathrm{CN})_{6}\right]^{4-/ 3-}$ probe for the bare platinum and modified Pt electrodes in PBS, $\mathrm{pH} 7.2$, at a scan rate of $50 \mathrm{mVs}^{-1}$. The Pt surface was modified with polyaniline bio-film (PANI@ $\mathrm{Fe}_{2} \mathrm{O}_{3}-\mathrm{Ge}-\mathrm{GA}-\mathrm{CRL}$ ). It can be seen that, for a bare $\mathrm{Pt}$ electrode, a characteristic quasi-reversible redox cycle with anodic and cathodic peak currents was obtained. When the Pt surface was functionalized with PANI@ $\mathrm{Fe}_{2} \mathrm{O}_{3}$ and lipase enzymes, the electron transfer between the redox probe and the modified surface was changed. As a result, an obvious decrease of the anodic and the cathodic peaks was observed, leading to a high $\Delta \mathrm{Ep}$ and indicating the formation of a bioactive layer. 
Electrochemical impedance spectroscopy can also give detailed information on the dielectric constant and the barrier properties of the deposit layer changes. Figure 5B shows the impedance spectra of the bare and the modified platinum electrode. The bare Pt electrode reveals a very small semicircle, implying a very low electron transfer resistance (Ret) of the redox probe. When the electrode is modified with PANI@ $\mathrm{Fe}_{2} \mathrm{O}_{3}$-Ge-GA-CRL film, the Ret increases significantly. The deposit film was defined with negatively charged $\left(\mathrm{COO}^{-}\right)$of the enzyme (amino acids containing carboxyl $(-\mathrm{COOH})$ functional groups), which acts as an electrostatic barrier that resists the $\left[\mathrm{Fe}(\mathrm{CN})_{6}\right]^{4-/ 3-}$ redox probe and hinders its ability to diffuse into the layer. This phenomenon probably results from the inhibition of the electron transfer kinetics between the redox probe and the surface of the modified electrode.

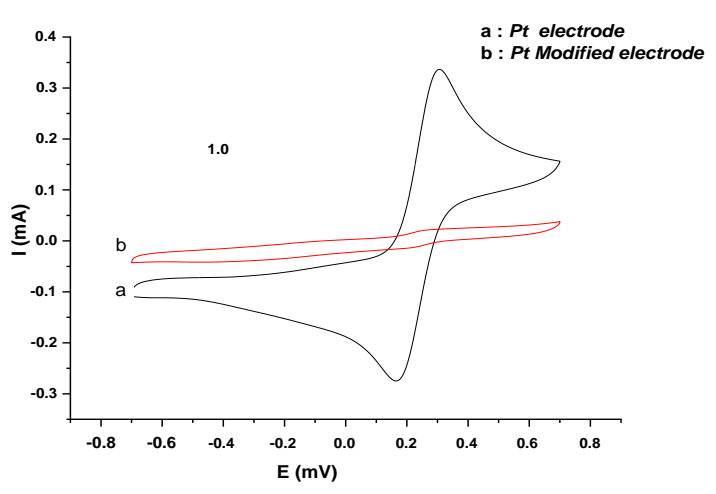

(A)

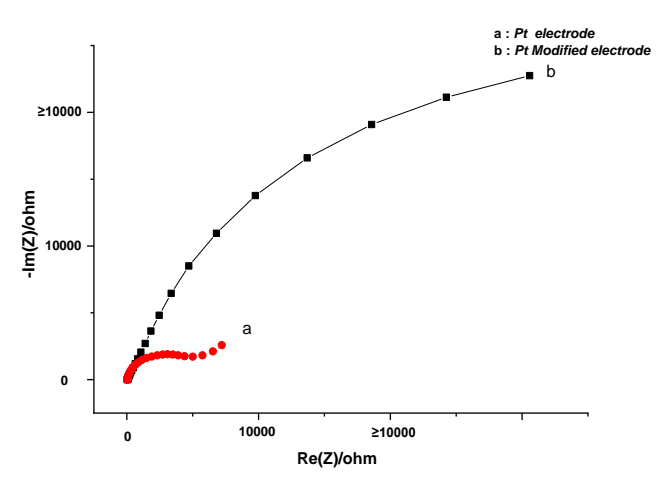

(B)

Figure 5. (A) Voltammograms at $50 \mathrm{mVs}^{-1}$ and (B) Diagram of Nyquist at $-200 \mathrm{mV}$ potential, of (a) Pt bare electrode and (b) Pt electrode modified with an enzymatic membrane in phosphate buffered saline (PBS) solution $(0.1 \mathrm{M})$. In the presence of $\mathrm{Fe}\left(\mathrm{CN}_{6}\right)^{3-/ 4-}$.

\subsection{Cyclic Voltammetry Study of the Biosensor}

\subsubsection{Concentration Effect}

The electrochemical response of AMD was studied by performing cyclic voltammetry in a solution containing between $10^{-12}$ and $10^{-6} \mathrm{M}$ of AMD at the CRL-PANI@ $\mathrm{Fe}_{2} \mathrm{O}_{3} / \mathrm{Ge}-\mathrm{Pt}$ electrode. The cyclic voltammograms recorded at this electrode are shown in Figure 6 . The cyclic voltammetry plots of AMD show a prominent cathodic peak at $\approx-0.18 \mathrm{~V}$, while no anodic peak is observed in the reverse scan, indicating the irreversible reduction of AMD at the electrode surface.

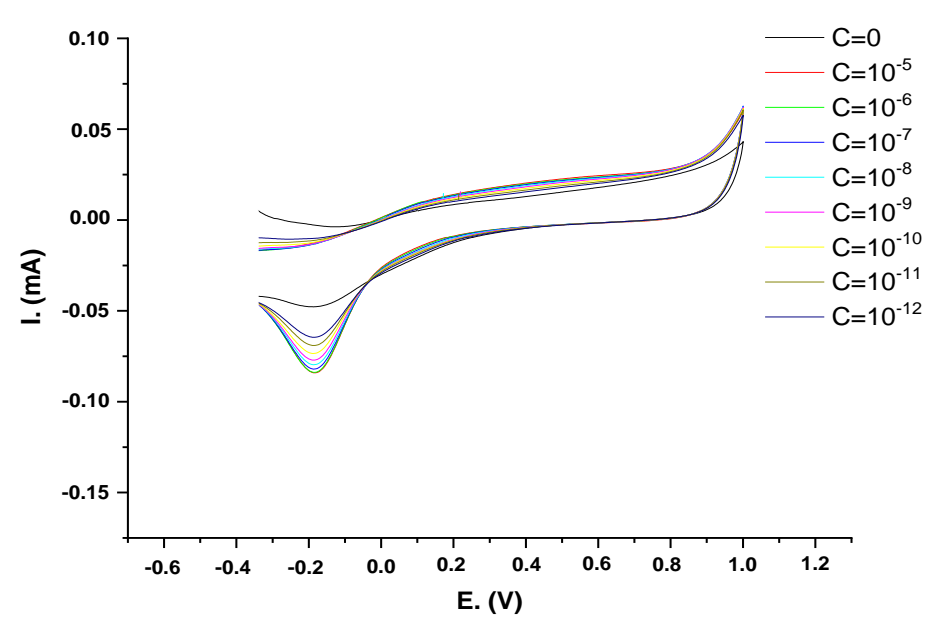

Figure 6. CV voltammograms of various AMD concentrations in $5 \mathrm{mM}$ PBS at $\mathrm{pH}$ 7.4. 
A calibration curve was plotted between the magnitude of current response and logarithm of amlodipine concentration (Figure 7). A linear dependent relation was observed, which followed the equation:

$$
\mathrm{Y}=7.6 \times 10^{-2}+3.5 \times 10^{-3} \cdot \log (\text { AMD concentration); } R=0.993 .
$$

The electrochemical amlodipine lipase sensor developed by us exhibited a wide linearity from $10^{-12} \mathrm{M}$ to $10^{-5} \mathrm{M}$ (on a logarithmic scale), as well as a low detection limit of $10^{-12} \mathrm{M}$ with a regression coefficient of 0.993 .

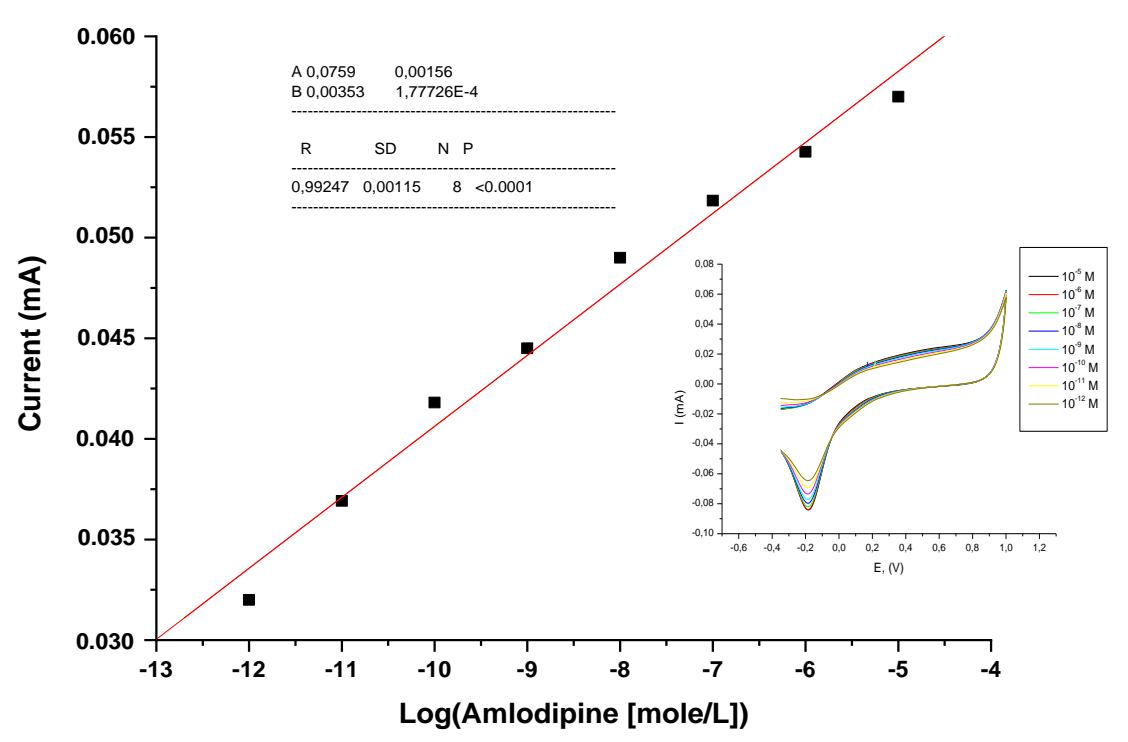

Figure 7. The relationship between peak current and logarithm of amlodipine concentration.

\subsubsection{Proposed Reaction Mechanism for Amlodipine}

The kinetic of catalytic reaction of the enzyme is one of the most important parts in the development of a biosensor.

For this purpose, kinetics were investigated in order to provide detailed information on the elementary reaction steps of the hydrolysis of the 1,4-dihydropyridine class (including the amlodipine substrate used in our study) by lipase. These 1,4-DHPs, including nifedipine and amlodipine, were subjected to enzymatic kinetic resolution via hydrolysis in the presence of lipases in water saturated with organic solvent [37,38].

In 1992, lipase was observed in the hydrolysis of 1,4-dihydropyridine derivatives by Hirose et al. A new series of 4-aryl-1,4-dihyropyridines are being used as substrates for many enzymes to obtain enantiopure compounds. The enzymatic hydrolysis of Candida rugosa by purified lipase has been investigated using 1,4-dihyropyridine diester as a substrate [39].

Lipase from Pseudomonas sp. catalyzed the hydrolysis of ethoxycarbonylmethyl esters of 1,4-DHP through the splitting of both 'outer' and 'inner' ester groups to give the corresponding carboxylic acid or methyl ester [40].

In addition, the hydrolysis of of 4-(3-nitrophenyl)-1,4-DHP was carried out by Holdgrun and Sih (1991) and Sih et al. (1992) in phosphate buffer at pH 7.0 with different lipases. When the reaction medium was n-butanol/water (10:1), the lipase-catalyzed hydrolysis proceeded with good enantioselectivity. The degradation of diesters was achieved through a two-step reaction (Scheme 1); the first step produced monoacids, and prolongation of the reaction time led to achiral di-acids [41,42]. 


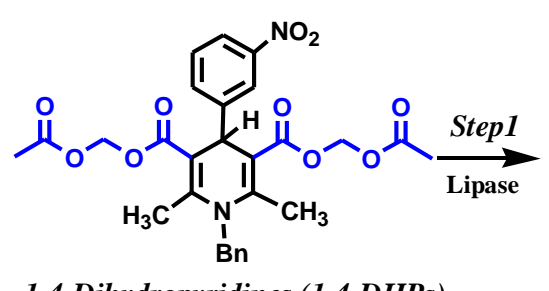

1,4-Dihydropyridines (1,4-DHPs) Di-Ester<smiles>CC1=C(C(=O)O)C(C(=O)OCOC(=O)CCC(C)C)(c2ccccc2)C(C(=O)O)=C(C)N1Cc1ccccc1</smiles>

Acid-Ester<smiles>CC1=C(C(=O)O)C(C(=O)O)(c2ccccc2)C(C(=O)O)=C(C)N1Cc1ccccc1</smiles>

Di-Acid

Scheme 1. Kinetic enzymatic hydrolysis of racemic 1,4-DHPs with two steps [41,42].

Using t-butyl methyl ether as the solvent in addition to methanol as the nucleophile for Pseudomonas lipase and water as the nucleophile for C. rugosa lipase (CRL), the transformations of 1,4-DHPs were investigated (Scheme 2) [43].<smiles>CC(=O)OCOC(=O)C1=C(C)N(Cc2ccccc2)C(C)=C(C(=O)OCOC(C)=O)C1c1cccc([N+](=O)[O-])c1</smiles>

1,4-Dihydropyridines (1,4-DHPs)

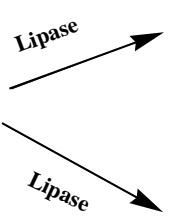<smiles>CC(=O)OCOC(=O)C1=C(C)N(Cc2ccccc2)C(C)=C(C(=O)O)C1c1cccc([N+](=O)[O-])c1</smiles><smiles>CC(=O)OCOC(=O)C1=C(C)N(Cc2ccccc2)C(C)=C(C(=O)O)C1c1cccc([N+](=O)[O-])c1</smiles>

Scheme 2. Kinetic enzymatic hydrolysis of racemic 1, 4-DHPs [43].

In our study, we used amlodipine as the substrate for Candida rugosa lipase. The enzymatic kinetics of the hydrolysis reaction were studied using CV with varied substrate concentrations. We only observed one peak on the first negative scan at a potential of about $-0.18 \mathrm{~V}$ (SCE), with no reversal peak in the positive scan. The one irreversible peak shown in this study indicated that only one dominant reaction occurs. We are able to propose the mechanism of the enzymatic transformations (Scheme 3).

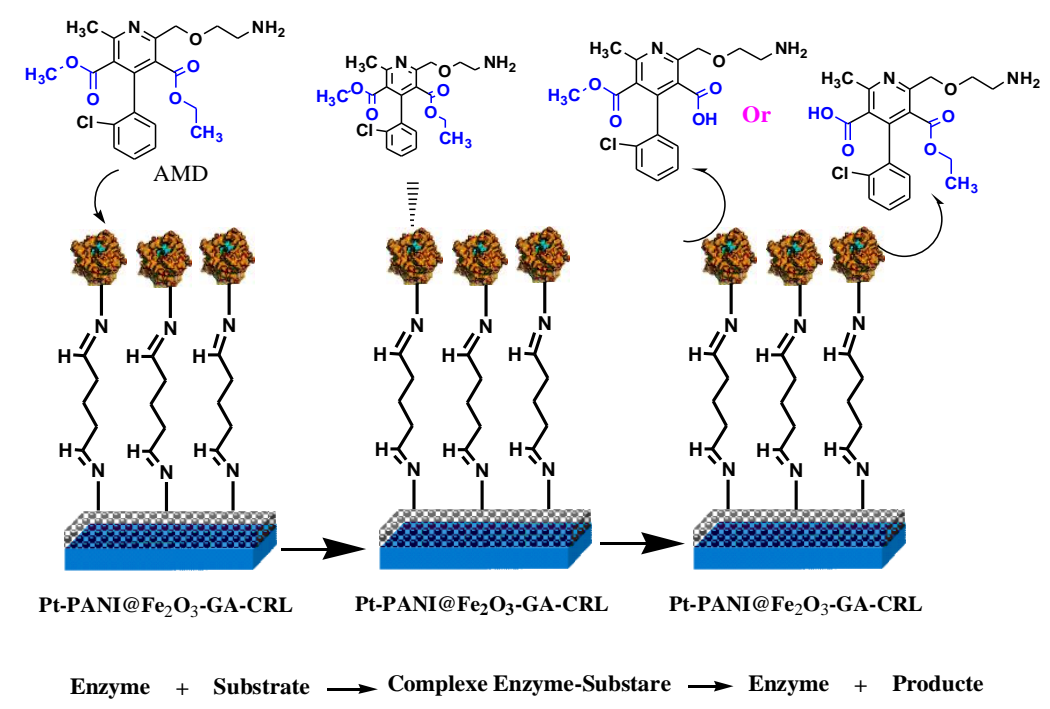

Scheme 3. Proposed kinetic enzymatic hydrolysis CRL of AMD (our work). 


\subsubsection{Scan Rate Effect}

The effect of scan rate on the peak current was studied by performing CV in $1.0 \times 10^{-6} \mathrm{M}$ AMD at various scan rates ranging from 50 to $200 \mathrm{mVs}^{-1}$ (Figure 8). The CV plots show an increase in the cathodic peak current with the increasing scan rate, with a shift in the peak potential to more negative values. These studies showed irreversible chemical behavior at the surface of the bioactive layer. Furthermore, the cathodic peak current shows a linear dependence on the square root of the scan rate, implying that the electrochemical reduction of AMD at the electrode surface is diffusion-controlled (Figure 8). A fit to the current gives the following regression equation:

$$
\mathrm{I}_{\mathrm{p}}=-0.03+0.01161 \cdot v^{1 / 2}, R=0.998 .
$$

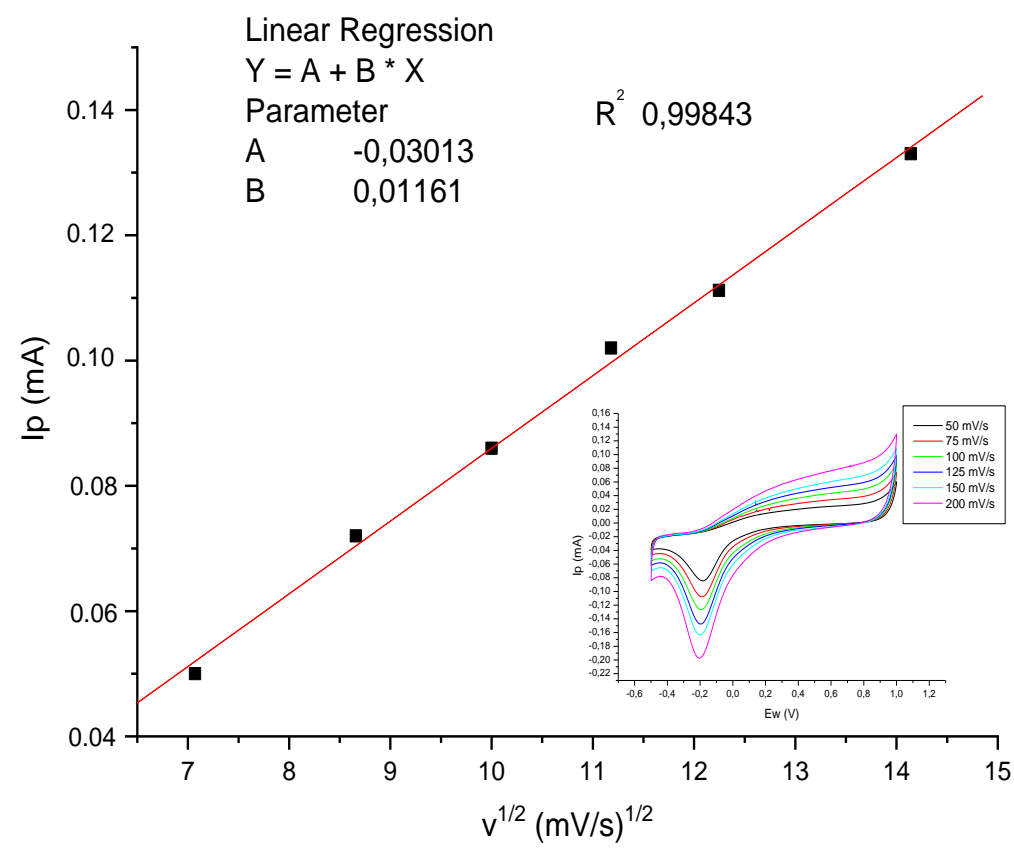

Figure 8. $\mathrm{CV}$ voltammograms of $1.0 \times 10^{-6} \mathrm{M}$ AMD in PBS at $\mathrm{pH} 7.4$ on Pt-modified electrode for series of scan rates from 50 to $200 \mathrm{mV} \mathrm{s}^{-1}$.

\subsection{Optimization of Working Conditions}

\subsection{1. $\mathrm{pH}$ Effect on Biosensor Response}

Generally, the effect of $\mathrm{pH}$ of the supporting electrolyte on the current response of the monitored analyte plays an important part in its detection and quantification [44]. The $\mathrm{pH}$ of the medium has an important role in biosensor studies for obtaining the best biosensor response. In order to determine the effect of the $\mathrm{pH}$ value on the biosensor response, different buffer systems were investigated. Phosphate buffers containing $1.0 \times 10^{-6} \mathrm{M}$ AMD were used in the experiments and all of the buffers had a concentration of $50 \mathrm{mM}$. From the experiments, the optimum $\mathrm{pH}$ value was found to be 7.4 (Figure 9). The response at $\mathrm{pH} 7.4$ was set to $100 \%$. Below and above $\mathrm{pH} 7.4$, decreases were observed in the biosensor response. 


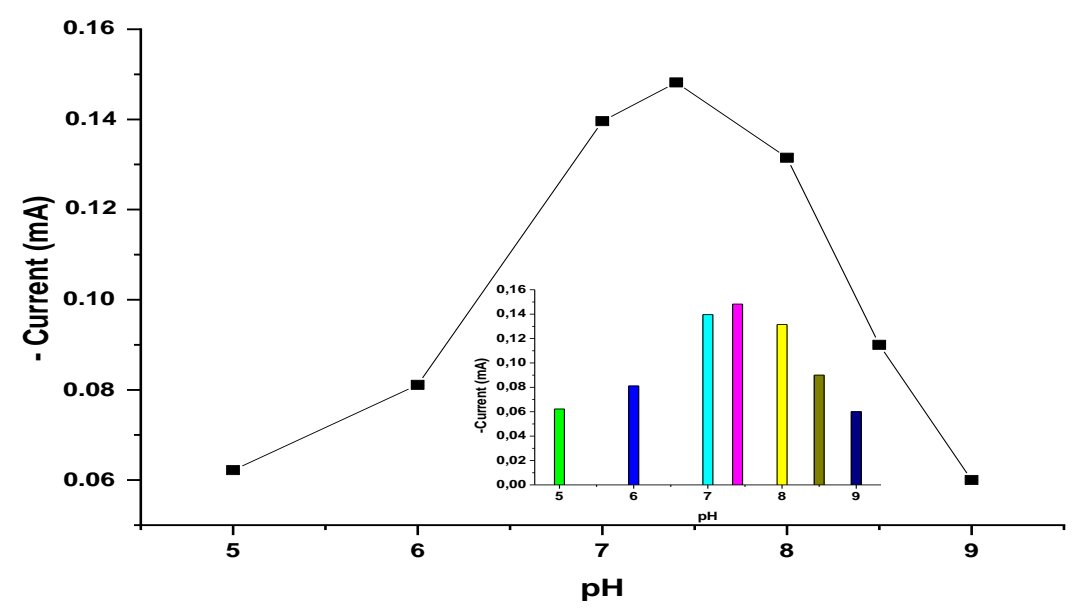

Figure 9. The effect of $\mathrm{pH}$ on the biosensor response. [Working conditions; phosphate buffer, $50 \mathrm{mM}$ and $\mathrm{T}=35^{\circ} \mathrm{C} .5 \mathrm{mg} / \mathrm{mL}$ amlodipine solution].

\subsubsection{Effect of Temperature on Biosensor Response}

To determine the influence of temperature on the response of the biosensor, experiments were carried out between 25 and $50{ }^{\circ} \mathrm{C}$ under the best working conditions obtained from the optimization studies. Results are given in Figure 10. The results showed that the best biosensor response was obtained at $35{ }^{\circ} \mathrm{C}$. Below and above this temperature, decreases in the biosensor response were recorded.

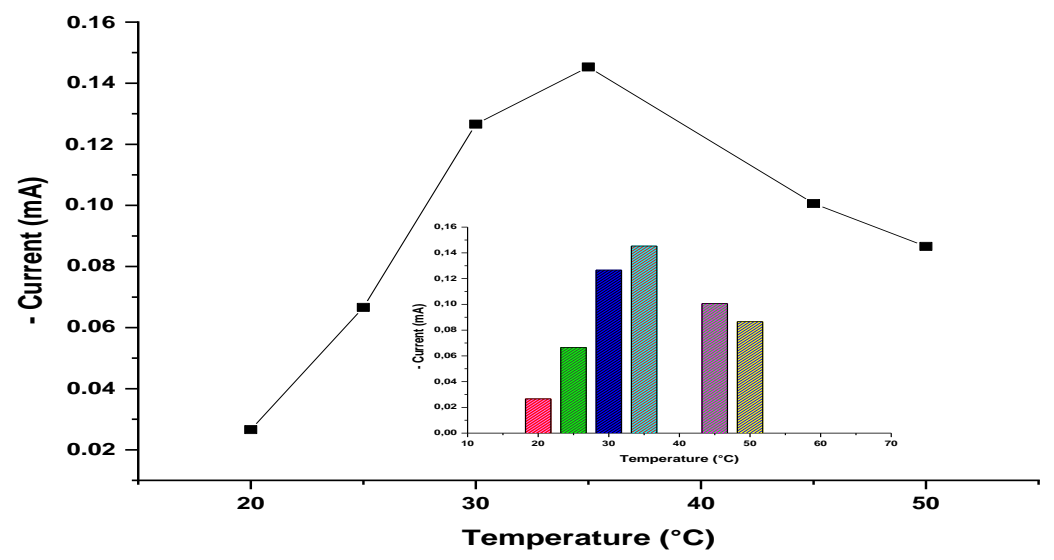

Figure 10. The effect of temperature on the biosensor response. [Working conditions; phosphate buffer, $50 \mathrm{mM}$ and $\mathrm{pH}=7.4,5 \mathrm{mg} / \mathrm{mL}$ amlodipine solution].

\section{Experimental}

\subsection{Apparatus}

The electrochemical experiments were conducted using an EC-Lab SP Modular Research Grade Potentiostat/Galvanostat, and the software EC-Lab was used for the treatment of the data and the control of the experiments. A three-electrode cell was used to study the electrochemical behavior of this material via cyclic voltammetry and electrochemical impedance spectroscopy (EIS); the reference electrode was a saturated calomel electrode (SCE), a platinum wire with a diameter of $1 \mathrm{~mm}$ was used as the auxiliary electrode, and the working electrode was a plate with an area of $0.5 \mathrm{~cm}^{2}$. In dynamic measurements, impedance data was obtained at an $\mathrm{AC}$ amplitude of $10 \mathrm{mV}$ and a frequency range 
varying from $100 \mathrm{~Hz}$ to $100 \mathrm{kHz}$. The experiments were performed in a dark faraday box to eliminate electrical interferences.

\subsection{Chemicals and Reagents}

All chemicals were commercially available and used as received. Candida rugosa lipase, purchased from Sigma Chemical Life Science (JABAN, Tiemcen, Algeria), was used for experiments without further purification. Aqueous solutions $(25 \% w / v)$ of glutaraldehyde (GA) were purchased from Sigma-Aldrich, hydrogenchloride $(\mathrm{HCl})$, monomer aniline, ammonium persulfate $\left(\left(\mathrm{NH}_{4}\right)_{2} \mathrm{~S}_{2} \mathrm{O}_{4}, \mathrm{APS}\right)$, iron oxide $\left(\mathrm{Fe}_{2} \mathrm{O}_{3}\right)$, and gelatin. Pure amlodipine besylate was obtained from MM LABORATOIRES (Annaba, Algeria). The buffer solution used for all experiments was phosphate buffered saline (PBS), containing $140 \mathrm{mM} \mathrm{NaCl}, 2.7 \mathrm{mM} \mathrm{KCl}, 0.1 \mathrm{mM} \mathrm{Na}_{2} \mathrm{HPO}_{4}$, and $1.8 \mathrm{mM} \mathrm{KH}_{2} \mathrm{PO}_{4}$, with a $\mathrm{pH}$ of 7.4. The reagents were of analytical grade and used as purchased without any further pretreatment. All solutions were prepared using demineralized water.

\subsection{Preparation of PANI/Iron Oxide}

The synthesis of PANI-iron oxide was carried out using a chemical polymerization method. For the activation of the aniline molecule, aniline monomer $(0.1 \mathrm{M})$ was mixed in $1 \mathrm{M} \mathrm{HCl}$ and stirred for $15 \mathrm{~min}$ to form aniline hydrochloride (Solution A). Then, $0.2 \mathrm{~g} \mathrm{Fe}_{2} \mathrm{O}_{3}$ microspheres were added as a mass fraction to the above solution with vigorous stirring in order to keep the iron oxide homogeneously suspended in the solution and subsequently sonicated for $30 \mathrm{~min}$, resulting in a homogeneous mixture. To this solution, $0.1 \mathrm{M}$ ammonium persulfate activated by $1 \mathrm{M} \mathrm{HCl}$ (Solution $\mathrm{B}$ ), which acts as an oxidizer, was slowly added dropwise with continuous stirring at $4-5^{\circ} \mathrm{C}$ for $5 \mathrm{~h}$ to completely polymerize the mixture (Scheme 4 ). The precipitate was filtered, washed with deionized water and acetone, and finally dried in an oven for $24 \mathrm{~h}$ to achieve a constant mass [44,45].

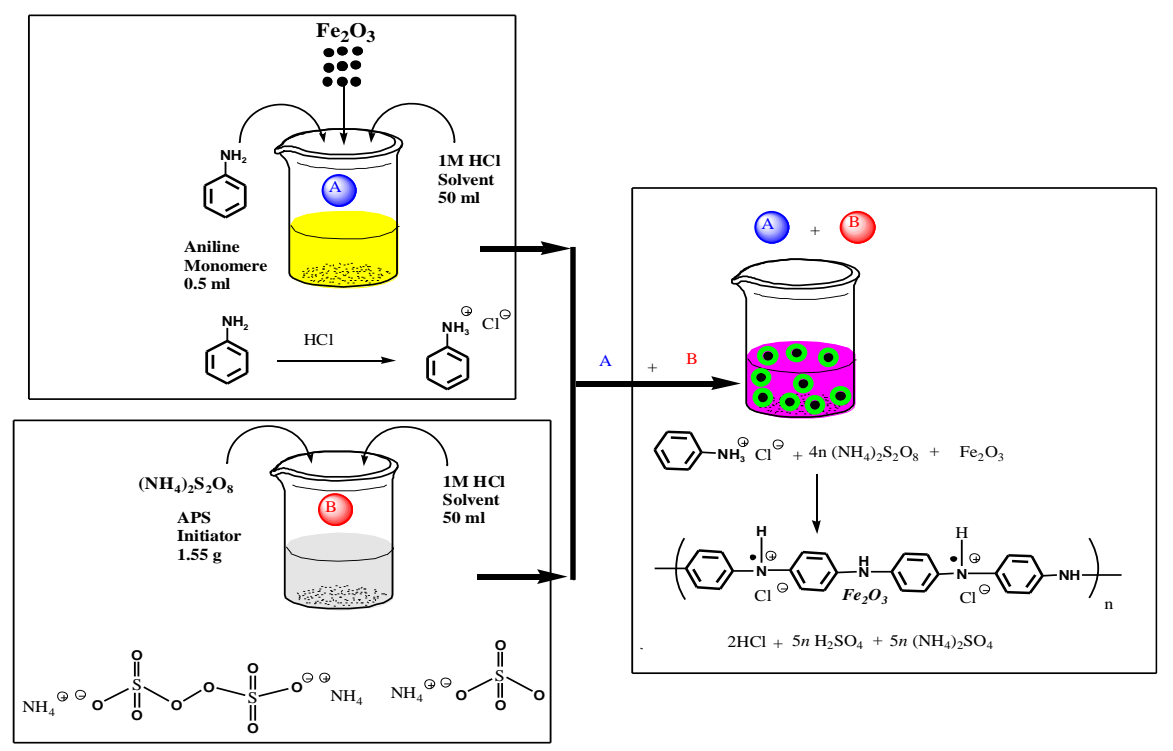

Scheme 4. Schematic representation of synthesis of $\mathrm{PANI} @ \mathrm{Fe}_{2} \mathrm{O}_{3}$ composite by chemical polymerization.

\subsection{Electrode Modification and Immobilization of the Enzyme Candida rugosa Lipase}

For the construction of the bioactive layer, the Pt electrodes were polished on a piece of velvet with alumina slurry, washed thoroughly with distilled water, and then sonicated for $5 \mathrm{~min}$ in ethanol and distilled water, respectively. Two milligrams of PANI@ $@ \mathrm{Fe}_{2} \mathrm{O}_{3}$ and $3 \mathrm{mg}$ of gelatin were dissolved in $100 \mu \mathrm{L}$ (pH 7.4) of a $50 \mathrm{mM}$ phosphate buffer at $40^{\circ} \mathrm{C}$. Then, $80 \mu \mathrm{L}$ of the solution was dispersed on 
the Pt electrode surface, and allowed to dry for $30 \mathrm{~min}$ at $4{ }^{\circ} \mathrm{C}$. For cross-linking, the electrode surface was immersed in glutaraldehyde solution $(5 \% v / v)$ for $5 \mathrm{~min}$. Then, $5 \mathrm{mg}$ Candida rugosa lipase were immobilized on the surface of the electrode. Finally, the electrode was rinsed with distilled water to eliminate the excess glutaraldehyde (Scheme 5).

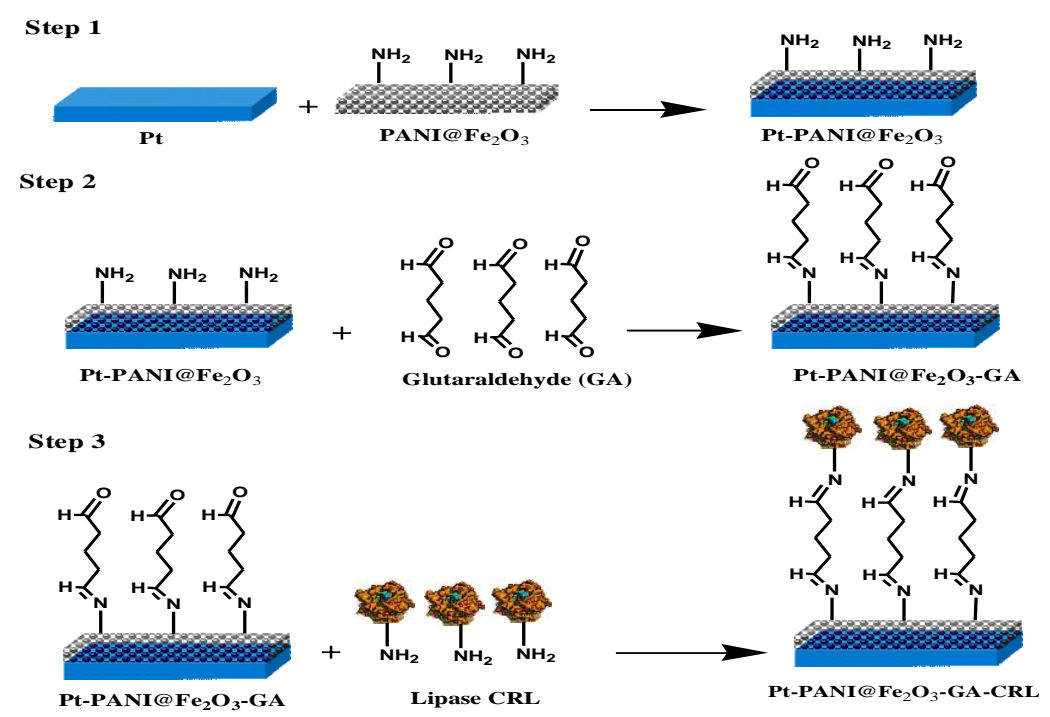

Scheme 5. Schematic of the biosensor elaboration using PANI@ $\mathrm{Fe}_{2} \mathrm{O}_{3}$.

\section{Conclusions}

Conducting polyaniline@ $\mathrm{Fe}_{2} \mathrm{O}_{3}$ composites have been synthesized successfully by a simple chemical procedure. The FTIR analysis confirms the chemical structure of PANI@ $\mathrm{Fe}_{2} \mathrm{O}_{3}$. UV-vis spectra confirm the formation of doped polymers.

The present study showed that the CRL/Ge-PANI@ $\mathrm{Fe}_{2} \mathrm{O}_{3}$-modified Pt electrode was a very good candidate for the construction of a sensitive CRL biosensor for AMD analysis. The cathodic behavior of AMD was measured on the irreversible reduction signal at -0.185 . It would be interesting to investigate other biosensors based on lipase for the analysis of 1,4-DHPs drugs.

Author Contributions: E.D. conceived and designed the experiments; M.E.H.S. and S.Z. analyzed the data; R.K. contributed reagents/materials/analysis tools; E.D. wrote the paper.

Acknowledgments: This work was supported by the Laboratory of Environmental Engineering, Department of Process Engineering, University of Annaba, Algeria. We thank our colleagues working in the Center for scientific and technical research in Physico-chemical analysis (CRAPC) Bou Ismail, Tipaza, Algeria.

Conflicts of Interest: The authors declare no conflicts of interest.

\section{References}

1. Evtugin, G. Biosensors: Essentials, Lecture Notes in Chemistry; Springer: Heidelberg, Germany, 2014; Volume 84.

2. Karyakin, A.A.; Vuki, M.; Lukachova, L.V.; Karyakina, E.E.; Orlov, A.V.; Karpachova, G.P.; Wang, J. Processible polyaniline as an advanced potentiometric $\mathrm{pH}$ transducer. Application to biosensor. Anal. Chem. 1999, 71, 2534-2540. [CrossRef] [PubMed]

3. Cho, J.H.; Shin, M.C.; Kim, H.S. Electrochemical adsorption of glucose oxidase onto polypyrrole film for the construction of a glucose biosensor. Sens. Actuators B 1996, 30, 137-141. [CrossRef]

4. Dhand, C.; Das, M.; Datta, M.; Malhotra, B.D. Recent advances in polyaniline based biosensors. Biosens. Bioelectron. 2011, 26, 2811-2821. [CrossRef] [PubMed]

5. Popovic, N.; Jugovic, B.; Jokic, B.; Knezevic-Jugovc, Z.; Stevanovic, J.; Grgur, B.; Gvozdenović, M. Electrochemical template-free synthesis of nanofibrous polyaniline modified electrode for ascorbic acid determination. Int. J. Electrochem. Sci. 2015, 10, 1208-1220. 
6. Gerard, M.; Chaubey, A.; Malhotra, B.D. Application of conducting polymers to biosensors. Biosens. Bioelectron. 2002, 17, 345-359. [CrossRef]

7. Martina, V.; De Riccardis, M.F.; Carbone, D.; Rotolo, P.; Bozzini, B.; Mele, C. Electrodeposition of polyaniline-carbon nanotubes composite films and investigation on their role in corrosion protection of austenitic stainless steel by SNIFTIR analysis. J. Nanopart. Res. 2011, 13, 6035-6047. [CrossRef]

8. Lin, M.S.; Leu, H.J. A Fe $\mathrm{O}_{4}$-Based Chemical Sensor for Cathodic Determination of Hydrogen Peroxide. Electroanalysis 2005, 17, 2068-2073. [CrossRef]

9. Sungur, S.; Numanoglu, Y. Development of Glucose Biosensor by using Gelatin and Gelatin-Polyacrylamide Supporting Systems. Artif. Cells Blood Substit. Biotechnol. 2006, 34, 41-54. [CrossRef]

10. Arkhypova, V.N.; Dzyadevych, S.V.; Soldatkin, A.P.; El'skaya, A.V.; Jaffrezic-Renault, N.; Jaffrezic, H.; Martelet, C. Multibiosensor based on enzyme inhibition analysis for determination of different toxic substances. Talanta 2001, 55, 919-927. [CrossRef]

11. Emregul, E.; Sungur, S.; Akbulut, U. Immobilization of glucose oxidase onto gelatin for biosensor construction. J. Biomater. Sci. Polym. Ed. 2005, 16, 505-519. [CrossRef] [PubMed]

12. Baali, S.; Kherrat, R.; Zougar, S.; Djeghaba, Z.; Benamia, F.; Jaffrezic-Renault, N.; Haddour, N. Comparative Study of Responses of Two Enzymatic Biosensors Based on Lipase from Candida rugosa and Porcine Pancreas for Detection of Diclofop-Methyl. Sens. Transducers 2014, 11, 2021-2029. [CrossRef]

13. Zehani, N.; Kherrat, R.; Dzyadevych, S.; Jaffrezic-Renault, N.J. A microconductometric biosensor based on lipase extracted from Candida rugosa for direct and rapid detection of organophosphate pesticides. Int. J. Environ. Anal. Chem. 2015, 95, 466-479. [CrossRef]

14. Zehani, N.; Dzyadevych, S.V.; Kherrat, R.; Jaffrezic-Renault, N.J. Sensitive impedimetric biosensor for direct detection of diazinin based on lipases. Front. Chem. Anal. Chem. 2014, 2, 1-7.

15. Villeneuve, P.; Muderhwa, J.M.; Graille, J.; Hass, M.J. Customizing lipases for biocatalysis: A survey of chemical, physical and molecular biological approaches. J. Mol. Catal. B Enzym. 2000, 9, 113-148. [CrossRef]

16. Hou, C.T. Industrial Uses of Lipase in Kuo and Gardner ed. Lipid Biotechnology; Marcel Dekker Inc. Press: New York, NY, USA, 2002; Volume 159, pp. 387-397.

17. Bossert, F.; Vater, W. Dihydropyridines, a new group of strongly effective coronary therapeutic agents. Naturwissenschaften 1971, 58, 578. [CrossRef] [PubMed]

18. Goldmann, S.; Stoltefuss, J. 1,4-Dihydropyridines: Effects of chirality and conformation on the calcium antagonist and calcium agonist activities. Angew. Chem. Int. Ed. Engl. 1991, 30, 1559-1578. [CrossRef]

19. Martindale, S.S.C. The Complete Drug Reference, 37th ed.; The Pharmaceutical Press: London, UK, 2011.

20. Rahman, N.; Nasrul Hoda, M. Validated spectrophotometric methods for the determination of amlodipine besylate in drug formulations using 2,3-dichloro 5,6-dicyano 1,4-benzoquinone and ascorbic acid. J. Pharmabiomed. Anal. 2003, 31, 381-392. [CrossRef]

21. Rahman, N.; Singh, M.; Hoda, M.N. Application of oxidants to the spectrophotometric determination of amlodipine besylate in pharmaceutical formulations. IL Farm. 2004, 59, 913-919. [CrossRef] [PubMed]

22. Abdel-Wadood, H.M.; Mohamed, N.A.; Mahmoud, A.M. Validated spectrofluorometric methods for determination of amlodipine besylate in tablets. Spectrochim. Acta Part A Mol. Biomol. Spectrosc. 2008, 70, 564-570. [CrossRef] [PubMed]

23. Meyyanathan, S.; Suresh, B. HPTLC Method for the simultaneous determination of amlodipine and benazepril in their formulations. J. Chromatogr. Sci. 2005, 43, 73-75. [CrossRef] [PubMed]

24. Bahrami, G.; Mirzaeei, S. Simple and rapid HPLC method for determination of amlodipine in human serum with fluorescence detection and its use in pharmacokinetic studies. J. Pharm. Biomed. Anal. 2004, 36, 163-168. [CrossRef] [PubMed]

25. Zarghi, A.; Foroutan, S.; Shafaati, A.; Khoddam, A. Validated HPLC method for determination of amlodipine in human plasma and its application to pharmacokinetic studies. IL Farm. 2005, 60, 789-792. [CrossRef] [PubMed]

26. Klinkenberg, R.; Streel, B.; Ceccato, A. Development and validation of a liquid chromatographic method for the determination of amlodipine residues on manufacturing equipment surfaces. J. Pharm. Biomed. Anal. 2003, 32, 345-352. [CrossRef]

27. Monkman, S.; Ellis, J.; Cholerton, S.; Thomason, J.; Seymour, R.; Idle, J. Automated gas chromatographic assay for amlodipine in plasma and gingival crevicular fluid. J. Chromatogr. B Biomed. Sci. Appl. 1996, 678, 360-364. [CrossRef] 
28. Quaglia, M.; Barbato, F.; Fanali, S.; Santucci, E.; Donati, E.; Carafa, M.; Marianecci, C. Direct determination by capillary electrophoresis of cardiovascular drugs, previously included in liposomes. J. Pharm. Biomed. Anal. 2005, 37, 73-79. [CrossRef] [PubMed]

29. Altiokka, G.; Altiokka, M. Flow injection analysis of amlodipine using UV-detection. Die Pharm. 2002, 57, 500-508.

30. Matalka, K.; El-Thaher, T.; Saleem, M.; Arafat, T.; Jehanli, A.; Badwan, A. Enzyme linked immunosorbent assay for determination of amlodipine in plasma. J. Clin. Lab. Anal. 2001, 15, 47-53. [CrossRef]

31. Stoiljković, Z.Ž.; Ivić, M.L.A.; Petrović, S.D.; Mijin, D.Ž.; Stevanović, S.I.; Lačnjevac, U.Č.; Marinković, A.D. Voltammetric and Square-Wave Anodic Stripping Determination of Amlodipine Besylate on Gold Electrode. Int. J. Electrochem. Sci. 2012, 7, 2288-2303.

32. Goyal, R.N.; Bishnoi, S. Voltammetric determination of amlodipine besylate in human urine and pharmaceuticals. Bioelectrochemistry 2010, 79, 234-240. [CrossRef] [PubMed]

33. Erden, P.E.; Taşdemir, I.H.; Kaçar, C.; Kiliç, E. Simultaneous determination of valsartan and amlodipine besylate in human serum and pharmaceutical dosage forms by voltammetry. Int. J. Electrochem. Sci. 2014, 9, 2208-2220.

34. Altiokka, G.; Dogrukol-Ak, D.; Tuncel, M.; Aboul-Enein, H.Y. Determination of Amlodipine in Pharmaceutical Formulations by Differential-Pulse Voltammetry with a Glassy Carbon Electrode. Arch. Pharm. 2002, 335, 104-108. [CrossRef]

35. Arkan, E.; Karimi, Z.; Shamsipur, M.; Saber, R. An Electrochemical Senor for Determination of Amlodipine Besylate Based on Graphene-Chitosan nanoComposite Film Modified Glassy Carbon Electrode and Application in biological and pharmaceutical samples. Pharm. Sci. 2014, 3, 99-107.

36. Mansano, G.R.; Eisele, A.P.P.; Dall'Antonia, L.H.; Afonso, S.; Sartori, E.R. Electroanalytical application of a boron-doped diamond electrode: Improving the simultaneous voltammetric determination of amlodipine and valsartan in urine and combined dosage forms. J. Electroanal. Chem. 2015, 738, 188-194. [CrossRef]

37. Bandgar, D.K.; Navale, S.T.; Naushad, M.; Mane, R.S.; Stadler, F.J.; Patil, V.B. Ultra-sensitive polyaniline-iron oxide nanocomposite room temperature flexible ammonia sensor. RSC Adv. 2015, 5, 68964-68971. [CrossRef]

38. Abu-Thabit, N.Y. Chemical Oxidative Polymerization of Polyaniline: A Practical Approach for Preparation of Smart Conductive Textiles. J. Chem. Educ. 2016, 93, 1606-1611. [CrossRef]

39. Sathiyanarayanan, S.; Azim, S.S.; Venkatachari, G. Preparation of Polyaniline- $-\mathrm{Fe}_{2} \mathrm{O}_{3}$ Composite and Its Anticorrosion Performance. Synth. Met. 2007, 157, 751-757. [CrossRef]

40. Hirose, Y.; Kariya, K.; Sasaki, I.; Kurono, O.; Ebiike, H.; Achiwa, K. Drastic solvent effect on lipase-catalyzed enantioselective hydrolysis of prochiral 1,4-dihydropyridines. Tetrahedron Lett. 1992, 33, 7157-7160. [CrossRef]

41. Sobolev, A.; Franssen, M.C.; Vigante, B.; Cekavicus, B.; Zhalubovskis, R.; Kooijman, H.; Spek, A.L.; Duburs, G.; de Groot, A. Effect of acyl chain length and branching on the enantioselectivity of Candida rugosa lipase in the kinetic resolution of 4-(2-difluoromethoxyphenyl)-substituted 1,4-dihydropyridine 3,5-diesters. J. Organ. Chem. 2002, 67, 401-410. [CrossRef]

42. Holdgrun, X.K.; Sih, C.J. A chemoenzymatic synthesis of optically-active dihydropyridines. Tetrahedron Lett. 1991, 32, 3465-3468. [CrossRef]

43. Salazar, L.; Sih, C.J. Optically-active dihydropyridines via lipase-catalyzed enantioselective hydrolysis. Tetrahedron Asymmetry 1995, 6, 2917-2920. [CrossRef]

44. Švorc, L.; Cinková, K.; Sochr, J.; Vojs, M.; Michniak, P.; Marton, M. Sensitive electrochemical determination of amlodipine in pharmaceutical tablets and human urine using a boron-doped diamond electrode. J. Electroanal. Chem. 2014, 42, 86-93. [CrossRef]

45. Valezi, C.F.; Duarte, E.H.; Mansano, G.R.; Dall'Antonia, L.H.; Tarley, C.R.T.; Sartori, E.R. An improved method for simultaneous square-wave voltammetric determination of amlodipine and enalapril at multi-walled carbon nanotubes paste electrode based on effect of cationic surfactant. Sens. Actuators B Chem. 2014, 205, 234-243. [CrossRef]

(C) 2018 by the authors. Licensee MDPI, Basel, Switzerland. This article is an open access article distributed under the terms and conditions of the Creative Commons Attribution (CC BY) license (http:/ / creativecommons.org/licenses/by/4.0/). 